\title{
RUSSIAN HAGIOGRAPHY. REVIEW OF MAJOR SCHOLARLY STUDIES PUBLISHED IN ST. PETERSBURG FROM 2002-2007
}

The study of Russian hagiography, almost halted in the Soviet years under the conditions of the antireligious propaganda and censorship, has been obviously experiencing a revival over the last fifteen or twenty years. This is readily seen in the publications of the Department of Old Russian Literature at the Institute of Russian Literature and Art (Pushkinsky Dom) of the Russian Academy of Sciences and St. Petersburg State University, considered to be the most authoritative institutions in this field in St. Petersburg. Since they publish research work made by scholars from different regions of Russia and other countries, their publications can give a rather wide view of what has been going on in this sphere. The major aim of this review is to present the situation in Russian hagiography studies as seen in St. Petersburg publications and highlight the main achievements; we are also going to discuss some shortcomings of the works reviewed here, where we can and think necessary to do so.

\section{ARTICLES}

The most significant event in research on Russian hagiography over the last several years was the publication of the long awaited collection of articles Русская агиография: исследования, публикациии, полемика [Russian Hagiography: Studies. Publications. Polemics]. Санкт-Петербург, 2005. The collection was edited by two specialists from the Department of Old Russian Literature at the Institute of Russian Literature and Art, T. R. Rudi and S. A. Semyachko. Consisting of twenty five articles written by scholars, mostly philologists, from St. Petersburg, Novosibirsk, Syktyvkar, Moscow, Tver, and Pskov, the Collection begins with works devoted to general questions of Russian hagiography studies and articles on peculiarities of regional hagiographical traditions followed by the studies and publications of lives and services of individual saints. The latter block of articles fills about 
two thirds of the book. Most of the hagiographical texts in this Collection have been published for the first time. The following review presents the articles in the order they are arranged in the Collection. Some articles first published in the Collection were later included by their authors in monographs now published, so it seemed reasonable to review them together with the rest of the monograph in the Books section of this Review.

\section{О. В. Творогов (Санкт-Петербург), О “Своде древнерусских житий". - O. V. Tvorogov (St. Petersburg), On "The Code of Old Russian Lives of Saints"}

The article consists of two parts, the first being an introduction to the main part - the survey of 164 lives of Russian saints with author's comments on the existing publications and recent studies of each life. In the introduction to the survey the author argues that textual analysis remains the basis for any other kind of study of hagiographical writings and has to be established on examination of all existing copies of the text. To meet this demand the Department of Old Russian Literature at the Institute of Russian Literature and Art (Pushkinsky Dom) has initiated a project to detect all existing copies of texts of Russian lives of saints and compile a catalogue of them, thus continuing the work of the nineteenth century Russian scholar N. Barsukov, who published a catalogue of texts of Russian lives and services known to him (Источники русской агиографии [Sources of Russian Hagiography]. Санкт-Петербург, 1882). The future catalogue will become the first step towards the more important and voluminous goal - the publication of lives and related texts in accordance with modern rules, accompanied by textual, historical and literary study. Hagiographical writings composed by the Old Believers from the middle of the seventeenth century on will not be included in the catalogue; considered to be a very special tradition, they will be catalogued and published separately. The survey in the second part of the article shows where we are now with the existing publications and studies of the lives of saints. The appearance of such a survey is very actual, as there was no such thing since Словарь книжников и книжности Древней Руси [Dictionary of Writers and Books of Old Russia] was published in 19871998. However, the survey has a certain shortcoming: of all the new studies printed up to the moment of the survey publication (2005) it mentions in full only those that were published by the Department of Old Russian Literature at the Institute of Russian Literature and Art or 
by scholars of the same department, and also texts of hagiographical writings edited by A. S. Gerd and published by the St. Petersburg University Press in the Series "Памятники русской агиографической литературы" [Monuments of Russian Hagiographic Literature]. All other studies and publications of texts mentioned in the survey are dated not later than 2002, and some earlier printed works are not mentioned at all. The worst presented are provincial publications, while articles about Russian saints published through 2005 in volumes of the new Orthodox Encyclopedia and often containing the newest results of hagiographical studies are not mentioned at all and no notice about their omission is given.

\section{T. Р. Руди (Санкт-Петербург), Топика русских житий (во- nросы типологиu). - T. R. Rudi (St. Petersburg), Topoi of Rus- sian Lives of Saints (Questions of Typology)}

Topoi of Russian lives of saints are an almost unexplored field, and this article, devoted to their specifics and classification, represents a very important move in Russian hagiography studies. The author views the article as the preparatory stage for a future comprehensive study. Rudi considers as a topos any repeated element of a text, be it a short literary formula, a motive, a plot, or an idea. The choice of a topos is based on the two major principles: following "the literary etiquette" (a notion introduced by D. S. Likhachev) and focus on models (imitatio). The author examines how the topoi are used in Russian hagiographical writings devoted to representatives of this or that major type of sanctity (martyrs, holy bishops, holy monks, holy wives). The main conclusion she makes is that, while the topoi of imitatio of a certain kind are not firmly attached to a specific type of lives - for example, the imitatio Christi motive is common to all types of lives, since Christ is a sacral model for all types of saints, and the imitatio angeli and imitatio Mariae motives are not specific to the lives of the holy monks or holy wives respectively, - each type of sanctity has its major spiritual model, which determines the choice of the hagiographical topoi in each case. Looking ahead the author points out that further analysis and systematization of hagiographical topoi should aim to study the topoi "serving the hagiographical scheme." Rudi herself has performed an investigation of this kind studying the lives of the holy monks. She published the results in an article on the composition of the topoi in lives of the holy monks ("О композиции и топике житий преподобных") in Труды Отдела древнерусской ли- 
mературы [Works of the Department of Old Russian Literature], volume 57 (Санкт-Петербург, 2006). In this article she gives a detailed account of motives, ideas, and concrete literary formulas with numerous examples from Russian hagiographies of the holy monks and also of the founders of monasteries. At the end of her article Rudi suggests that such studies could be greatly promoted by compiling a dictionary of hagiographical topoi.

\section{Е. В. Крушельницкая (Санкт-Петербург), К вопросу об автобиографизме в древнерусской литературе. - E. V. Кru- shelnitskaya (St. Petersburg), Concerning Autobiographic Traits in Old Russian Literature}

The main goal of the article was to explain the author's method used in her earlier study of the genetics of autobiographic traits in Old Russian literature (Автобиография и житие в әревнерусской лиmepamype [Autobiography and Vita in Old Russian Literature]. Санкт-Петербург, 1996). The article was triggered by criticism on the part of O. N. Bakhtina who questioned the efficiency of E. V. Krushelnitskaya's method and her objective of finding autobiographic features in Old Russian hagiographical writings (О. Н. Бахтина. Старообрядеская литература и традиции христианского понимания слова [Old Believers' Literature and Traditions of Christian Understanding of the Word]. Томск, 1999). The conflict is imbedded in the differences of approaches. In her study O. N. Bakhtina considers a number of writings produced by the Old Believers together with several Old Russian writings composed before the Schism in the Russian Church and society. As E. V. Krushelnitskaya puts it, the problem is that treating all of these writings from the point of view of moral philosophy, O. N. Bakhtina stresses the common features, but does not discover the differences due to the turmoil of the epoch. E. V. Krushelnitskaya's own approach is based on genre differentiation and functional characteristics of hagiographical writings. In the article she examines three groups of writings related to hagiography and dated from the time before the Schism: 1) reports of witnesses gathered after some relics had been found; 2) "memoirs about venerated spiritual leaders," and 3) testaments of hegumen-founders of monasteries, containing monastic rules. The genre and functional analysis allow the author to argue that up to the middle of the seventeenth century pure autobiography was absent from Old Russian literature having no genre form, since narration about oneself was never the main goal 
of an author. On the contrary, the writings produced by the leaders of the Old Believers Epifany and Avvakum had distinct genre features brought about by the new concept of the main hero who was not passively contemplating any more, but acting and talking about himself. In the attachment to the article E. V. Krushelnitskaya publishes for the first time the narrative on "the death of elder Theodosy" (died in 1563) written by his disciple Evfimy Turkov (Ms. Russian State Library, fund 113, no. 512).

\section{С. А. Семячко (Санкт-Петербург), Проблемь изучения реги- ональных агиографических традиций (на примере вологод- ской агиографии). - S. A. Semyachko (St. Petersburg), The Problems of Studying Regional Hagiographical Traditions (the Case of the Vologda Hagiographical Writings)}

The author makes an attempt to establish the signs of a local hagiographical tradition using the case of the rather numerous Vologda hagiographical writings. S. A. Semyachko rejects the geographical (but in fact administrative) attribution used by other scholars who studied the question because the geographical content of what is now the Vologda region has been changing from century to century. Instead she argues for textological ties between the texts as the basis for reconstruction of a local tradition and offers a scheme for these ties in the lives of Vologda saints. Admitting the obvious merit of this approach - the focus on hagiography as a tradition preserved in texts, - one has to note that the group of lives studied by the scholar contains just the lives of the holy monks, and there should be some textual links based on typological ties. Besides, there are recognized textual connections between the hagiographical writings of the Vologda region and lives of the holy monks written in other parts of Russia, in particular, in the North, and this is not considered in the article either.

\section{Е. К. Ромодановская (Новосибирск), «Святой из гробниць»». O некоторьх особенностях сибирской и севернорусской агиографии. - E. K. Romodanovskaya (Novosibirsk), "Saints from the Tombs." On Some Special Features of Siberian and Northern Russian Hagiography}

The author studies a peculiar type of hagiographical writings which she calls "saints from the tombs." This type has not been previously selected and examined as special in Russian hagiographical studies. The scholar points out the common features of these texts: the story of the appearance of a tomb with a body considered to be the relics of a 
saint, a rather long period during which the saint remains anonymous, and a special structure of the text, that does not contain a life per se, but shows definite genetic ties with documentary records. The name of the saint and a few details about his life are revealed by the saint himself when he appears before someone who then reports these facts to be written. The following publication of the text of miracles of such a saint - Peter of Cherevkovo - illustrates the author's observations. However, the author's supposition that this type of hagiographical writings was mostly special to the Russian North and Siberia is not quite right, since there is evidence of similar cults developed in other parts of the Orthodox Christian world, for example, the veneration of some relics in the Crimea described by the priest Iakov Lyzlov in the 1630s.

\section{Е. А. Рьюжова (Ськтьвкар), Жанр видений в севернорусской azиографиu. - E. A. Ryzhova (Syktyvkar), The Genre of Vi- sions in Northern Russian Hagiography}

The author points out that themes of visions in Russian hagiography have not yet been fully studied and types of visions have not been defined. In great detail she describes peculiarities of form and content of visions focusing mostly on descriptions of post-mortem miracles of saintly founders of northern Russian monasteries. The author shows that saints in these miracles are presented as kind patrons of the people of the North, saving them from troubles, curing diseases, solving financial problems, helping in farming and trades. Ryzhova argues that the situations described in these miracles are very real, the "miraculous atmosphere" being created by the usage of special topoi at the appearance and disappearance of a saint. Throughout the text of the article she refers to the study of European folk culture of the Middle Ages done by A. Ya. Gurevich (Проблемы средневековой народной культури [Problems of Medieval Popular Culture]. Москва, 1981) to show that the themes of visions are quite common in different regional traditions. What is different between them is the content of the visions, for it is defined by the tradition of veneration of a particular saint and relics preserved in a monastery, and also "by the process of the spreading of a saint's veneration among the local people." The conclusions seem to lack examples of how the tradition of veneration and the process of the spreading of veneration actually influenced the content of the visions, but, unfortunately, this remains unclear from the article. 
Е. А. Рьжова (Ськтывкар), Виршевье редакции севернорусских житий. - E. A. Ryzhova (Syktyvkar), Verse Recensions of the Lives of Northern Russian Saints

The article presents the results of the first study of the form, content, date, authorship, and textual relations of verse recensions of lives of three northern Russian saints - Antony Sijsky, Nikodim Kozheozersky, and Loggin Koryazhemsky. In the appendix to the article texts of these lives written in verse are published for the first time.

Т. Ф. Волкова (Сыктывкар), Древнерусская и старообрядческая агиография в печорской рукописной традиции. T. F. Volkova (Syktyvkar), Old Russian and Old Believers' Hagiography in the Pechora Manuscript Tradition

The author studies Russian hagiographical writings composed before the Old Believer Schism and those written by the Old Believers themselves in the manuscript tradition of the peasant community of Old Believers at Ust'-Tsilema, being a part of a large region around Pechora river to the northwest of the Urals inhabited by Old Believers. The article is considered to be the first step of research and presents a review of manuscripts and general classification of hagiographical writings in manuscripts originating at Pechora and preserved now in collections at the Institute of Russian Literature and Art (St. Petersburg), Syktyvkar University Library, and the Library of the Academy of Sciences (St. Petersburg). The article is accompanied by a catalogue of hagiographical writings found in the Pechora manuscripts, showing dates of the manuscripts and the existing scholarly descriptions and studies.

О. А. Белоброва (Санкт-Петербург), Об изучении и публикации лицевых списков житий русских святых. - О. А. Веlobrova (St. Petersburg), On Research and Publication of Illuminated Manuscripts of Lives of Russian Saints

The author points out that while the illuminated manuscripts containing historical writings such as chronicles were fairly well studied in the Soviet years, the illuminated manuscripts of lives of Russian saints have no catalogue at all, and some even remain unknown to scholars. The author describes the principles used for the few publications of illuminated manuscripts with lives of Russian saints (St. Sergius of Radonezh, Boris and Gleb, Metropolitan Alexij, St. Nifont, St. Evfrosinia of Suzdal', Peter and Fevronia, and St. Zosima and Sav- 
vaty of Solovki, most published before 1917), and argues for publishing artworks together with the text of a manuscript and for compiling catalogues of such illuminated manuscripts.
А. А. Пичхадзе (Москва), В. А. Ромодановская (Санкт-Пе- тербург), Е. К. Ромодановская (Новосибирск), Жития кня- гини Ольги, Варяжских мучеников и князя Владимира в со- ставе Синайского палимпсеста (РНБ, Q.n.I.63). - A. A. Pich- khadze (Moscow), V. A. Romodanovskaya (St. Petersburg) and E. K. Romodanovskaya (Novosibirsk), The Lives of Princess Olga, the Varangian Martyrs and Prince Vladimir in the Sinai Palimpsest (Russian National Library, Q. p. I. 63)

The three synaxary ("prologue") lives of Russian saints are studied in the context of the contents of the Sinai palimpsest from the Russian National Library, where they are found among apocrypha and edifying writings. The authors argue that although the three lives are taken from a Prologue they do not represent some part of a prologue but rather a deliberate selection from it. This suggests a hypothesis that this selection reflects the traces of the eleventh century Story of the Spreading of Christianity in Russia detected by D. S. Likhachev within the most ancient layers of the Primary Chronicle. The manuscript dating to the thirteenth century and being a Bulgarian copy of a Russian protograph allows one to consider that the three lives were composed earlier than it was thought previously. The authors believe that these lives could have been composed in the eleventh century to be included in the Story, and were edited later to be included in the Church service. The publication of the three lives along with the article is accompanied by comments of codicological and language features of the manuscript and a publication of the corresponding fragment from the Russian Prologue of the sixteenth century from the Russian National Library, F. I. 495.

\section{М. А. Федотова (Санкт-Петербург), Житие Никить} Столпника Переяславского (рукописная традиция Жития). - M. A. Fedotova (St. Petersburg), The Life of Nikita the Stylite of Pereyaslavl' (the Manuscript Tradition)

The article presents a reconsideration of the history of the text of The Life of Nikita Stylite of Pereyaslavl' previously believed to exist in just one recension. Fedotova argues for three recensions: the Short recension (the earliest of the three), the Main recension (with four types and several groups inside each type), and the Prologue recension. She 
also reconsiders different opinions on the dating of the Panegyric to St. Nikita and gives reasons to believe that it was written at the same time as the Life, not before and not much later than it, and was included in the text of the Life by the end of the fifteenth century together with the description of the miraculous cure of prince Mikhail of Chernigov. The text of the Main recension (type A, group three, according to Fedotova) from the fifteenth century manuscript of the Russian State Library is published in the appendix to the article.

\section{А. Е. Смирнова (Санкт-Петербург), Службы Макарию Калязинскому: рукописная традиция, проблемы источ- ников, датировки и атрибуциии. - A. E. Smirnova (St. Peters- burg), Services to St. Makary Kalyazinsky: Manuscript Tradi- tion, the Problem of Sources, Date, and Attribution}

Theimpetus for this study was given by the acrostic with the abridged name of the Russian hagiographer and hymnographer of the sixteenth century Markell Bezborody (the Beardless) found by the scholar from Tver' G. S. Gadalova in several manuscript copies of the Prayer Service for the feast of St. Makary Kalyazinsky. The finding was readily caught up by A. E. Smirnova since at that time she was studying writings by Markell for her dissertation defended in December 2005. The article presents a reconstruction of the process of the hagiographer's work on the Service for the feast of Makary Kalyazinsky. Smirnova studied thirty six manuscripts dating from the sixteenth and the seventeenth centuries of the two liturgical cycles devoted to this saint - the Service for the feast of finding his relics (the first of the two services) and the Service for his memorial day (his death day), - and established three recensions of each service. Most of the article deals with the latter Service where the acrostic "MRKL" or "MAKL" is found in one of the two or in both Canons of the Service. Comparing this Service to the texts of the Service for the feast of St. Savva Krypetsky and the Service for the feast of St. Savva Storozhevsky, Smirnova argues that it was the author of the Service for the feast of St. Savva Krypetsky who borrowed fragments of the text from the latter services, not the other way around. In Smirnova's opinion the text of the Service for the feast of St. Makary Kalyazinsky is original, except for some minor borrowings from the Service for the feast of St. Varlaam Khutynsky and from the prayers in honor of those saints that have no proper office found in the Menologion. She also argues that the Service in question depends on the Prologue hagiography of St. Makary Kalyazinsky for some special data about the saint contained in the Service. Unlike G. S. Gadalova, 
who previously suggested that Markell Bezborody was just the editor, not the author of the Service, and added the acrostic with his abridged name while editing it, since some of the manuscripts do not contain this acrostic, Smirnova argues that Markell could have been the author of the whole Service writing both Canons and a later version of his own work, as well as adding the acrostic. To support her argument she offers some observations concerning the way the Service is edited and also speculates on the reasons for its editing and adding the acrostic with the name of the author. The most probable reason for the editing was in her opinion the change in the functional designation of the Service - the attempt to introduce it for use on the day of the feast of finding Makary's relics instead of the memorial feast day. This is suggested by the fact that the text containing the acrostic is placed on the day of the feast of finding the relics, not on the memorial feast day, where the earlier edition of the Service belonged.

Г. С. Гадалова (Тверь), Службы преподобному Макарию Калязинскому: к вопросу о комплексном подходе в изучении памятников. Публикация списков. - G. S. Gadalova (Tver'), Services to St. Makary Kalyazinsky: on the Question of a Complex Research Approach. Publication of the Manuscripts

G. S. Gadalova published the text of the Service for the memorial feast of St. Makary Kalyazinsky containing the acrostic with the abridged name of Markell Bezborody. The basic text of the publication is that of the manuscript from the Scientific Library of Moscow State University (МГУ НБОР и ОРК, № 1308) written in the 1590s. It is supplemented with variants drawn from five other manuscripts; a description of the manuscripts is published along with the article. Gadalova accepts the opinion that Markell might not have been just the editor, but also the author of the Service for the memorial feast of St. Makary and suggests that he also might have been the author of the Life, although she gives no support for this hypothesis.

\section{Ю.Г.Фефихова (Санкт-Петербург), Повесть оПетре и Фев- ронии в контексте традиционной обрядовой практики. - Yu. G. Fefilova (St. Petersburg), The Narration of Peter and Fev- ronia in the Context of Traditional Ritual Practice}

The author argues that the ambiguity of the content of the Narration of Peter and Fevronia, which is very unusual among Old-Russian writings, can be explained by the fact that although conceived as a hagiography, the Narration uses the language of folklore. Keeping this in mind one 
has to view the "marriage theme" that makes up the basis of the Narration as an allusion to the Eucharist, while the pagan component should be interpreted in the context of the ethnographic data on the rituals of the wedding and celebrating the Whitsun and Midsummer Night. The article is an attempt to bring all this together into a coherent interpretation.

\section{В. И. Охотникова (Псков), Житие Всеволода-Гавриила в составе Степенной книги. - V. I. Okhotnikova (Pskov), The Life of Vsevolod-Gavriil as a part of the Book of Degrees}

The article was included by the author in the first volume of her book Псковская агиография XIV-XVII веков: Исследования и тексть [Pskov Hagiography of the Fourteenth - Seventeenth Centuries: Studies and Texts], Санкт-Петербург, 2007, reviewed further in the Books section.

\section{Т. Б. Карбасова (Санкт-Петербург), История почитания преподобного Кирилла Новоезерского. - T. В. Karbasova (St. Petersburg), The History of the Veneration of St. Kirill Novo- yezersky}

Except for some general works published before 1917, studies in the history of the veneration of Russian saints are quite rare in Russian scholarship. This study in the history of veneration of St. Kirill Novoyezersky, the founder of a monastery in the Russian North, is based on careful analysis of the data of his Life, the text of the Prayer Service for his feast, menologies, documentary records (the letter of donation, monastery inventories, receipts and expenditure books), and iconography. The author argues that the veneration of Kirill Novoyezersky started soon after his death in 1532 and passed through several stages. Karbasova reconsiders the opinion of E. E. Golubinsky who suggested that the official canonization of Kirill Novoyezersky took place only in the middle of the seventeenth century after the finding of Kirill's relics. According to Karbasova, the official canonization occurred at the beginning of the year 1628, while the finding of the relics years later just contributed to the rise of his glory. The article is amended with the publication of the three miracles of Kirill Novoyezersky dating from the year 1627; their report in Moscow became, as Karbasova argues, the reason for the official canonization of the saint. She also publishes here the Oration on the finding of the relics of St. Kirill Novoyezersky in its first version.

Karbasova, who has been studying the Life of Kirill Novoyezersky and the Service for his feast for several years now has published sev- 
eral articles on the texts related to this saint. For example, there is a textological study and publication of the text of the Primary recension of the Life in Tруды Oтдела древнерусской литературы [Works at the Department of Old Russian Literature], volume 57 (Санкт-Петербург, 2006).

И. А. Аобакова (Санкт-Петербург), Памятник византийской учительной литературь «Поучение благого цһарства» Azапита и «Житие митрополита Филиппа». - I. A. Lobakova (St. Petersburg), Byzantine Exhortations "Chapters of Admonition" by Agapetus the Deacon and "The Life of Metropolitan Philip"

The article was included by the author in her book Житие митроnолита Фихиппа: Исследования и тексты [The Life of Metropolitan Philip: Study and Texts], published in St. Petersburg in 2006 and reviewed in the Books section.

О.С.Сапожникова (Санкт-Петербург), Сказание ояренгских чудотворияах и методы работы древнерусского автора. O. S. Sapozhnikova (St. Petersburg), Narration of the Yarenga Wonderworkers and Literary Techniques of an Old-Russian Author

The author studies literary techniques used by prominent Solovki writer and editor Sergey Shelonin in his Narration about Miracles of Yarenga Worderworkers St. Ioann and Loggin composed on the basis of records of miracles - a special kind of source material combining literary and documentary features. This is rare luck for a scholar of Old-Russian hagiography - two volumes containing materials and documents related to veneration of the Yarenga wonderworkers and two authorized manuscripts with the text of the Narration. They are preserved among manuscripts of the Solovki library, now at the Russian National Library, and at the Nikandrova Hermitage Fund of the Pskov Museum, enabling a study of the process of Shelonin's work. Sapozhnikova examines origins of insertions and thus reveals additional sources used by Shelonin to create a text that could put the cult of the Yarenga wonderworkers in the canonical tradition. To do so she uses well preserved books from Shelonin's own library containing his remarks. Sapozhnikova also gives attention to the analysis of the role of Sergey Shelonin in the context of the Russian book culture of the seventeenth century, comparing Shelonin's manner of writing to that of his contemporary - archpriest Avvakum. She argues that 
while both of them were fond of studying and using in their writings recently printed texts of Church Fathers not known in the Russian manuscript tradition before, their attitudes toward the rules of the genre were different: while Avvakum was struggling for truthful reflection of the life around him and by doing this was actually destroying the genre, Shelonin found new resources within the traditional structure of hagiography by enriching his hagiographical writings with the best Byzantine works previously absent from this popular genre. In the appendices to the article Sapozhnikova publishes for the first time the text of the Narration as it is in the Pskov manuscript with variants drawn from the Solovki manuscript (Russian National Library) with her commentaries, and also Sergey Shelonin's Note on the translation of the relics of Ioann and Loggin of Yarenga from the only manuscript at the Solovki Library (RNL), and the text of a charter with description of a miracle which occurred with Solovki iconographer Feodorit Gubasty (Thick-lipped), also from the Solovki library manuscript.

\section{А. А. Романова (Санкт-Петербург), Житие Вассы (Феодо- ры) Нижегородской: Пространная (Компилятивная) редак- цุия. - A. A. Romanova (St. Petersburg), The Life of Vassa (Feo- dora) of Nizhny Novgorod: the Long (Compiled) Recension}

A. A. Romanova publishes the text of the Long, or Compiled, recension of the Life of Vassa (Feodora) of Nizhny Novgorod using one of the two known manuscripts of this recension of the Life as a basic text and drawing variants from the other manuscript. Peculiarities of this recension in comparison to the Short recension of the same Life are discussed in the article going with the publication. Observing the compiling character of this recension Romanova points to the Life of Eufrosinia of Polotsk as the main source for borrowings.

\section{Е. А. Рьюжова (Съютьюкар), Житие Варлаама Важского (Пинежского) в рукописно-книжной традиции 16-19 вв. - E. A. Ryzhova (Syktyvkar), The Life of Varlaam Vazhsky (Pine- zhsky) in the Manuscript Tradition of the Sixteenth-Nineteenth Centuries}

The article is the first published work specially devoted to the manuscript tradition of the Life of Varlaam Vazhsky, a Novgorod boyar who established a monastery in the northeastern part of European Russia in the first half of the fifteenth century, his Life being written more than a century after his death. Ryzhova names twenty 
five manuscripts containing the text of the Life in different recensions. She gives a very detailed description of the Main recension preserved in nineteen manuscripts and divides manuscripts with text in this recension into two branches with a special variant belonging to one of the branches. She also gives textological reasons for considering one of the branches to be a more accurate reflection of the original text than the other. Each of the five other manuscripts presents a new recension, three of them making a chain of extensions of the Main recension. The main features distinguishing these recensions are the new miracles and some new data that allow the scholar to connect these new recensions to the monastery founded by Varlaam and to call them "Northern recensions." The two other manuscripts represent two different Short recensions, one composed on the basis of some branch of the Main recension, the other - on the basis of the third Northern recension. One more manuscript contains a short extract from the Life seeming to be a historical note. Ryzhova admits that she could not examine all the manuscripts she named, and there are some more manuscripts containing the Life of Varlaam Vazhsky that were not included in her list. It also remains desirable to trace more accurately the relations between the manuscripts of different recensions and to extend the analysis of the relations between the manuscripts within the Main recension. These remarks aside, the article is a solid first step in studying the manuscript tradition of this piece of Russian hagiography.

\section{Е. В. Крушельницкая (Санкт-Петербург), Житие Филиппа}

Ирапского: Вторая редакция (публикация текста). E. V. Krushelnitskaya (St. Petersburg), The Life of Philip Irapsky: The Second Recension (Publication of the Text)

Having found several previously unknown manuscripts containing the text of the Life of Philip Irapsky, E. V. Krushelnitskaya publishes the text of the Second recension (type B, according to her identification) of this writing taken from the only preserved manuscript dating from the end of the eighteenth century. In the article accompanying the publication the scholar describes three versions of the Life. She argues that the difference between them is due to gradual perfection of the text with respect to style and composition, and also in reinforcement of special features of hagiography as a genre: the three recensions show the shift from personal recollections about the saintly man towards an impersonal hagiography with all sources fully integrated into the text. 


\section{Е. М. Юхименко (Москва), Выговские похвальные слова Але- ксандру Свирскому. - E. M. Yukhimenko (Moscow), Panegy- rics of Alexander Svirsky Composed by the Vyg Authors}

Three Panegyrics of St. Alexander Svirsky composed by three eighteenth-century writers of the Vyg Old Believers' community are analyzed in the context of other Old Believer records of the time, and are published here. The first Panegyric was authored by the famous Old Believer writer Andrey Denisov in 1720. It shows what facts about Alexander Svirsky's life could make this saint especially dear to the members of the Vyg community. Yukhimenko argues that the second Panegyric composed by an anonymous writer was a revision of Denisov's text with extensive inserts that helped to strengthen main topics of the Old Believers' polemics, reflected their bitterness about the rejection they met on the part of the government and Church hierarchy, and also called Old Believers of the Vyg community to improve their life, repent and pray for help and protection. From the scholar's point of view, these features of the second Panegyric place it well within other writings produced or edited at the Vyg community in the 1740s, particularly the second version of the Pomorsky Torzhestvennik [Pomor Homeliary], thus suggesting the tentative date of the Panegyric. The third Panegyric was written by another famous Vyg author Trifon Petrov; Yukhimenko dates it not later than the 1730s and points out that like other writings by this author the Panegyric is distinguished by prevalence of general Christian values instead of a narrow Vyg orientation.

\section{В. И. Охотникова (Псков), Поздние редакциии Жития Псков- ского князя Всеволода-Гавриила. - V. I. Okhotnikova (Pskov), Late Recensions of the Life of Pskov Prince Vsevolod- Gavriil}

The article was included by the author in the first volume of her book Псковская агиография XIV-XVII веков: Исследования и тексты [Pskov Hagiography of the Fourteenth-Seventeenth Centuries: studies and texts], published in St. Petersburg in 2007, and is reviewed in the Books section.

\section{Е. Э. Шевченко (Санкт-Петербург), История создания Жи- тия преподобного Ниха Сорского. - E. E. Shevchenko (St. Pe- tersburg), The History of the Life of St. Nil Sorsky}

Shevchenko presents a study of several manuscripts of the Manuscript Department of the Russian National Library (St. Petersburg) 
containing a group of writings devoted to St. Nil Sorsky, his life, death, and miracles, some of them published but not studied before. Among these writings there are short records about Nil Sorsky's death written in the middle of the sixteenth century, first records of his miracles dating from the end of the seventeenth century, the Narration of Nil Sorsky's skete composed by I. I. Pleshkov, short biographical texts, records of miracles dating from the turn of the nineteenth century, and, eventually, the Life of Nil written by hieromonk Nikon (Prikhudailov) in the 1840s. The main approach used by the scholar is to examine these texts in chronological order, trying to uncover ties between them. Shevchenko sees them as related stages of the process of selecting materials, the probable aim being canonization of Nil Sorsky. The date of his canonization and the process that led to it are subjects of dispute. This article does not give the answer to this question, but Shevchenko doubts the date suggested by another scholar - E. V. Romanenko, who argued that the canonization took place at the end of the seventeenth century (Нил Сорский и традициии русского монашества [Nil Sorsky and Russian monastic traditions]. Москва, 2003. 194-195). The difference in opinions is due to the fact that Shevchenko is inclined to consider as accurate one record about a funeral service (панихида) for Nil Sorsky in the manuscript dated not earlier than 1808 according to watermarks of the paper (date "1808"). Despite the fact that there are two other manuscripts dating from the end of the eighteenth century and the 1820s that include a Troparion, Kontakion, and Oikos in honor of Nil Sorsky, she argues that the contents of the former manuscript are better structured, and for that reason its text represents a new stage in development of the corpus of writings devoted to Nil Sorsky. While Romanenko believes that the record about a funeral service (панихидa) for Nil Sorsky in this manuscript could be an accidental repeat of some old note, Shevchenko refutes this possibility. It follows from this that Nil Sorsky was not canonized yet when the manuscript was written in about 1808. The article is amended with the publication of miracles of Nil Sorsky from the manuscript of the second third of the eighteenth century from the Russian National Library previously published by A. S. Arkhangelsky at the end of the nineteenth century, now printed according to modern rules accepted for publications at the Department of Old Russian Literature at the Institute of Russian Literature and Art. 
И. А. Аобакова (Санкт-Петербург), Заметки по текстологии «Повестей о Николе Заразском» (Отклик на концепцุию Б. М. Клосса). - I. A. Lobakova (St. Petersburg), Notes on Textology of "Narrations about Nikola Zarazsky" (Response to the Concept of B. M. Kloss)

The author comments on the concept of the date and sources of "Narrations about Nikola Zarazsky" recently advocated by B. M. Kloss, a Moscow scholar famous for his surprising ideas that break away from traditional approaches. Lobakova sees the root of the problem with this concept in the fact that Kloss does not separate two different texts united in the Zarazsky cycle: «Сказание о перенесении Николина образа из Корсуни в Рязань» ("The Narration of Transferring Nikola's Image from Korsun to Ryazan") and «Повесть о разорении Рязани Батыем» (“The Narration of the Destruction of Ryazan by Batu Khan"). Studying them as a single text, Kloss ascribes specific fifteenth and sixteenth century features characteristic of the former text to the whole cycle and thus to the latter Narration. Lobakova also attacks Kloss' textological methods that led, in Lobakova's opinion, to complete confusion and false results. The last part of the article is devoted to criticism of Kloss' assertion that "The Narration of the Destruction of Ryazan" was composed on the basis of the so called Московский летописный свод [Mоscow Chronological Collection] or Moscow Codex of 1479. Lobakova argues that the opposite is more probable.

$$
* * *
$$

Similar to the articles published in the "Russian hagiography" collection, other recently published studies deal mostly with the literary history of Russian hagiographical texts and accompany long-awaited publications of these texts. Several such publications appeared in recent volumes of Труды Отдела древнерусской литературы [Works at the Department of Old Russian Literature]. However, recent years witnessed certain development in studying intertextual features of Russian hagiography. The most significant publications in this area are the two articles by T. R. Rudi reviewed above, and the article by $\mathbf{O}$. V.Panchenko (St. Petersburg), Поэтика уподоблений (к вопросу о «типологическом» методе в древнерусской агиографии, эпидейктике и гимнографии) [Poetics of assimilation (concerning the question of "typological" method in Old Russian hagiography, epideictics, and hym- 
nography)], published in Труды Отдела древнерусской литературь [Works of the Department of Old Russian Literature], volume 54 (Санкт-Петербург, 2004). Although it is commonplace that assimilation of new saints to the tradition by likening them with biblical heroes and earlier saints are basic features of hagiographic texts, the article by Panchenko is the first special study of main assimilation principles in Russia. The article begins with discussion of the notion of a "hagiological model," or "hagiotype" as Panchenko calls it, and two methods of assimilation. The scholar supports the idea of a concrete and individual character of the "hagiological model" in Russian hagiography suggested by V. N. Toporov in his book Святость и святые в русской духовной культуре [Sanctity and Saints in Russian Spiritual Culture] published in Moscow in 1995, as opposed to the categorization of the hagiographical model characteristic of Western hagiography. Panchenko uses the term "hagiotype" or "hagiological model" for Christian saints who could be perceived as models. The ways of assimilation of the model could be, in Panchenko's words "verbal" - through comparison, syncrisis, or translatio nominis, or "non-verbal" - through borrowing fragments of some canonical text and substituting the new character for the hagiological model. Panchenko has also compiled a list of hagiotypes of some Russian saints detected by other scholars, followed by a brief overview of the theme of likening (or assimilation) in patristic writings which leads to the conclusion that the "literary method of assimilation with 'hagiological models' reflects the long standing spiritual experience of Christian anthropology" (p. 501). The second part of the article is devoted to the use of biblical models in hagiography and is largely based on the ideas of Friedrich Ohly. In the third and largest part of the article Panchenko shows how the assimilation principle was used by one of the prominent Russian writers of the seventeenth century Sergey Shelonin to select hagiological and biblical models and create literary likeness in his «Похвальное слово русским преподобным» ("Panegyric of the Russian holy monks") written according to the model of the «Похвальное слово преподобным отцам и женам» ("Panegyric of the holy fathers and nuns") by the fourteenth-fifteenth century Bulgarian writer Gregory Tsamblak. Panchenko detects thirteen different reasons used by Sergey Shelonin to make his choice for this or that Christian hagiotype or biblical type. The article is completed with a table showing the "verbal" models (hagiotypes and biblical types) of Russian saints in Shelonin's Panegyric and their "hidden hagiotypes" from the Panegyric by Gregory Tsamblak along with the reason for every choice. 


\section{BOOKS}

The last several years have been especially fruitful in the field of the long awaited publication of texts of Russian hagiographical writings, making them more accessible to scholars. Some of the publications aim at publishing just one recension of the text, others present different recensions. The latter are accompanied by a more or less profound study of literary tradition and, sometimes, of other aspects as well.

A series of publications of lives of Russian saints which was begun in 2000 by a group of scholars from the department of philology of St. Petersburg State University, has been continued over recent years. So far the group has published lives of several northern Russian saints of the fourteenth - sixteenth centuries: Kirill Belozersky (2000), Alexander Svirsky (2002), Antony Sijsky (2003), Kirill Novoyezersky (2003), Dimitry Prilutsky, Dionisy Glushitsky, and Gregory Pelshemsky (2003), Kornily Komelsky (2004), Pavel Obnorsky and Sergey Nuromsky (2005), Ioasaph Kamensky, Alexander Kushtsky, and Euphymy Syanzhemsky (2007). ${ }^{1}$ Each publication is based on one manuscript and preserves the peculiarities of its spelling, accentuation, and punctuation. The editors separate words, written in pre-modern Russian manuscripts without spaces in between, but do not disclose abridged words offering corresponding readings from other manuscripts when interpretation of the text is vague. Each text is accompanied by a word index and a short article on the manuscript tradition. The books published in 2004, 2005, and 2007 are amended with articles on the history of Vologda monasteries. These publications are definitely intended for philologists, but possess a certain merit for historians too, since most of the lives either had no earlier publications at all, or were published in a way far from any scholarly approach.

(1) И. В. АЗАровА, Е. Л. АлексеЕВА, Л. А. ЗАХАровА, К. Н. ЛЕмешеВА (сост.), А. С. ГеРд (ред.), Житие Александра Свирского (Санкт-Петербург: Издательство Санкт-Петербургского университета, 2002); ІDEм, Житие Кирилла Новоезерского (Санкт-Петербург: Издательство Санкт-Петербургского университета, 2003; іDем, Жития, Димитрия Прилуикого, Дионисия Глуиицкого и Григория Пельшемского (Санкт-Петербург: Издательство Санкт-Петербургского университета, 2003); А. С. Герд (ред.), Житие Корнилия Комельского (СанктПетербург: Издательство Санкт-Петербургского университета, 2004); IDEм, Жития Павла Обнорского и Сергия Нуромского (Санкт-Петербург: Издательство Санкт-Петербургского университета, 2005); іDем, Жития Иоасафа Каменского, Александра Куштского и Евфимия Сянжемского (Санкт-Петербург: Издательство Санкт-Петербургского университета, 2007). 
Г. М. Прохоров и С. А. Семячко (подготовка изд.), Святые подвижники и обители Русского Севера: Усть-Шехонский Троицикий, Спасо-Каменньй, Дионисьев Глушицикий и Александров Куштский монастьри и их обитатели (СанктПетербург, 2005). - G. M. Prokhorov and S. A. Semyachko (eds.), Saintly Hermits and Monasteries of the Russian North: Ust'-Shekhonsky Trinity Monastery, St. Saviour of the Stone Monastery, Dionisy Glushitsky Monastery, and Aleksander Kushtsky Monastery and Their Inhabitants (St. Petersburg, 2005)

The book is devoted to the history of several monasteries of the Vologda region and saintly monks who established or lived in them. The editors' main goal was to publish narrative and documentary texts related to these monasteries. These texts include a number of hagiographical writings: the "Life of Ioasaph Kamensky" (studied and published by Prokhorov), the "Life of Dionisy Glushitsky" in ten versions, two different texts of the "Life of Amphilokhy Glushitsky," the "Life of Alexander Kushtsky" in six versions, and the joint "Life of Alexander Kushtsky and Euphimy Syanzhemsky" (all studied and published by Semyachko). The publication of each life is introduced by a study devoted to the history of the corresponding monastery and literary history of these lives. The articles cannot be considered comprehensive; however, they definitely advance the study of the subject. This is especially true about the two articles by Semyachko devoted to the "Life of Dionisy Glushitsky" and the "Life of Alexander Kushtsky." The scholar names many more manuscripts containing these two pieces of hagiography than the number known to prerevolutionary scholars, reconsiders old opinions concerning their literary history, and introduces a new view of it. The "Life of Dionisy Glushitsky" in this edition is published from the same manuscript as in the publication of 2003 reviewed above, but, as Semyachko notes, she checked the text again for this new publication, and some passages were interpreted differently by her. The "Life of Dionisy Glushitsky" is also presented in this edition with a translation into modern Russian made by Prokhorov.

Н. В. Рамазанова (подготовка текста и иссдедование), Святье русские римляне: Антоний Римский и Меркурий Смоленский (Санкт-Петербург, 2005). - N. V. Ramazanova (publication of text and study), Saintly Russian Romans: Antony of Rome and Merkury of Smolensk (St. Petersburg, 2005)

Ramazanova accomplished a study of hagiographical writings and prayer services devoted to two Russian saints different in their hagio- 
graphical status (one being a warrior, the other - a monk), but having one feature in common - their "Roman" origin. Previous studies of these hagiographical texts treated them separately, while Ramazanova compares them and examines the role of the "Roman" origin in each case. The scholar points to the fact that Roman relics in Novgorod are first mentioned in Russian (Novgorod) literature at the end of the sixteenth century (besides relics related to Antony of Rome, there were several others), while the spear and the shield of Merkury of Smolensk, as well as the saint himself, are mentioned first already in the 1530s. Despite the opinion of other scholars, who studied the Life of Antony of Rome, Ramazanova argues that there is nothing in it that could suggest a separatist, anti-Moscow trend. From her point of view the Roman relics in Novgorod had to do more with the rise in status of the Novgorod church organization, the head of which became a metropolitan in 1589, than with the reaction to the loss of political independence of Novgorod. So, Roman relics added to the spiritual authority of Novgorod. The texts related to Merkury of Smolensk appeared after the conquest of Smolensk by the Russian army and the incorporation of the city into Muscovy. The constant military threat and proximity of Western lands stimulated the veneration of this saintly warrior. Ramazanova also suggests that Merkury's Roman origin can be connected to the legendary genealogy of Russian tsars descending from Roman emperors; the theory was well known in the sixteenth century. Very interesting is the question of naming enemies in the texts devoted to Merkury of Smolensk. Ramazanova notes that there is a certain pattern in the use of words naming enemies: for example, there is no such word as "Tatars" in the whole cycle. As Ramazanova explains, at the time when the cycle was composed the Tatars were Russian allies in the struggle against the Lithuanians, and for that reason even the warriors of Khan Batu are called not Tatars, but "evil barbarians". The fact that none of the real ethnic groups are named as enemies (except for the "Pechenegs" - nomads who vanished in the eleventh century, whose name remained in Russian literature to call any non-Christian enemies) is due, in Ramazanova's opinion, to Merkury's peculiar ability acquired after his death: when summoned by the Mother of God, he comes to defend Smolensk from any foe. Although there are strong local motives in Merkury's cycle, Ramazanova points to features in the texts that make him, as well as Antony, an all-Russian saint. The scholar ties the emergence of these two saints with Roman origin in the Russian hagiographical tradition with "Moscow the third Rome" theory developed in the course of the late fifteenth and sixteenth centuries. 


\section{И. А. Добакова, Житие митрополита Филиппа (Санкт- Петербург, 2006). - I. A. Lobakova, The Life of Metropolitan Philip (St. Petersburg, 2006)}

Lobakova presents a study of the literary history of a very popular hagiographical text devoted to one of the most prominent Russian Church leaders - Metropolitan Philip, who lived in the sixteenth century and was murdered on the order of Ivan the Terrible. The scholar describes six recensions of the Life of Metropolitan Philip and argues that the short recension of the Life was composed earlier than the long recension, previously thought to be the basis for the short one. Discussing literary sources of the Life of Metropolitan Philip, Lobakova compares the text of the Life to the text of exhortations composed in Byzantium in the sixth century by Agapetus the Deacon and known as Поучение

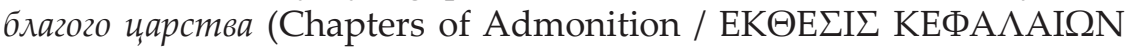
$\Pi A P A I N E T I K \Omega N)$. She argues that the Byzantine text was an important source for the author of the Life of Metropolitan Philip in the so called Tulupov Menology (the Tulupov Menology recension), who cited Agapetus' work twenty three times and, as a rule, incorporated whole chapters of the Byzantine author into his text. Lobakova also notes that the authors of the two earlier recensions of the Life - the Short recension and the Milyutinskaya recension - included phrases from this Byzantine source in their texts independently from each other. This, in her opinion, can be an additional argument to support Ihor Ševčenko's hypothesis that the Chapters of Admonition by Agapetus the Deacon were one of the sources of real exhortations with which Metropolitan Philip addressed Ivan the Terrible.

\section{В. И. Охотникова, Псковская агиография XIV-XVII веков:} Исследования и текстьл. 2 тома (Санкт-Петербург, 2007). - V. I. Okhotnikova, Pskov Hagiography of the FourteenthSeventeenth Centuries: Studies and Texts. 2 vols (St. Petersburg, 2007)

This voluminous study is unique in Russian hagiography scholarship as it embraces the most important texts of one regional hagiographical tradition and covers the whole period of its existence (the study does not really stop at the 17th century, but includes also eighteenth and nineteenth century recensions of earlier hagiographical texts). Its other merit is incorporation of prayer services into the study. In these two volumes Okhotnikova presents her studies of literary tradition and literary sources of lives and prayer services devot- 
ed to prince Vsevolod-Gavriil, Dovmont, Euphrosin Polotsky, Savva Kryptesky, and Nikandr Pskovsky. The study of each recension is accompanied by a description of manuscripts and a publication of its text. The scholar also makes many interesting observations concerning ideas expressed in different recensions of these hagiographical writings. The great volume of the study and limited space here compel us to keep from discussing them.

$$
* * *
$$

When trying to analyze the results of the recent development of Russian hagiography studies found in Saint Petersburg publications, one can see several features specific to this new period. First, it is obvious that most of the studies present publications of hagiographical texts that either have not been published before, or had some prerevolutionary publication that does not correspond to modern scholarly rules and aims. This very urgent task is well understood by scholars. Secondly, along with publication the hagiographical texts are being analyzed using textological methods. There is still a lot of work to do, as many pieces of hagiography still lack publication and proper textological analysis. Thirdly, it is very satisfying that the scholars do not confine their studies to mere textological questions. Some attempts are made to study regional hagiographical traditions; of course, these attempts appear more sound when anticipated or accompanied by publications and textological studies of all texts thought to belong to one tradition. Several attempts have been made to discover some special types of hagiographical texts within the Northern Russian tradition and to study their characteristic features. Drawing hymnographical material into analysis of hagiographical writings also seems rather fruitful. Recent years have also seen the beginnings of intertextual analysis of such features of hagiography as topoi and assimilation principles - areas that until now remained untouched in Russian scholarship. It seems that Russian hagiography studies are experiencing a definite revival after decades of prohibition and neglect, although it is equally clear that we are witnessing just the beginning of the process. 